\title{
A mechanochemical approach to access the proline-proline diketopiperazine framework
}

\author{
Nicolas Pétry ${ }^{1}$, Hafid Benakki ${ }^{1,2}$, Eric $\mathrm{Clot}^{3}$, Pascal Retailleau ${ }^{4}$, Farhate Guenoun ${ }^{2}$, \\ Fatima Asserar ${ }^{2}$, Chakib Sekkat ${ }^{2}$, Thomas-Xavier Métro ${ }^{*}$, Jean Martinez ${ }^{1}$ \\ and Frédéric Lamaty ${ }^{* 1}$
}

\section{Full Research Paper}

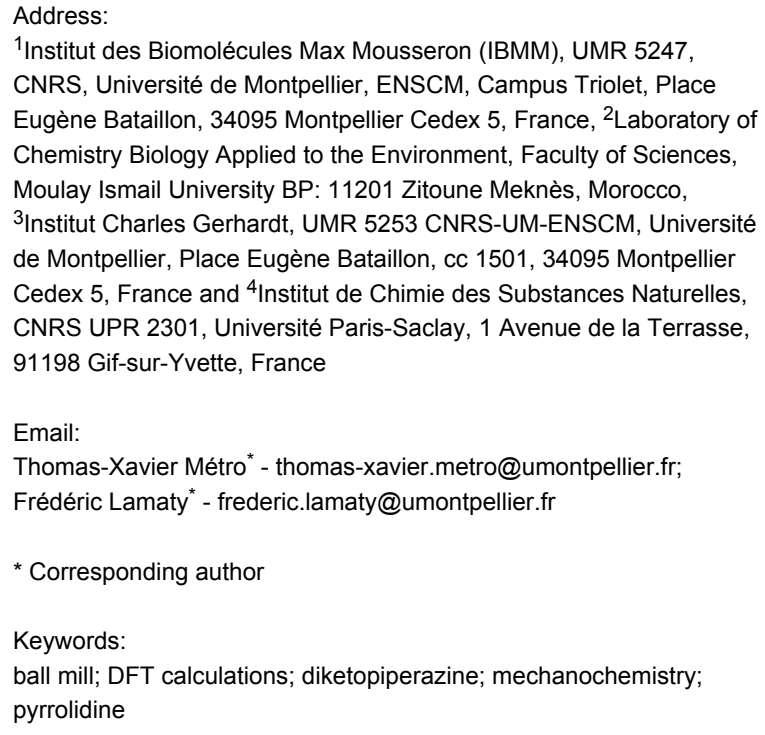

${ }^{1}$ Institut des Biomolécules Max Mousseron (IBMM), UMR 5247, CNRS, Université de Montpellier, ENSCM, Campus Triolet, Place Eugène Bataillon, 34095 Montpellier Cedex 5, France, ${ }^{2}$ Laboratory of Chemistry Biology Applied to the Environment, Faculty of Sciences, Moulay Ismail University BP: 11201 Zitoune Meknès, Morocco, ${ }^{3}$ Institut Charles Gerhardt, UMR 5253 CNRS-UM-ENSCM, Université de Montpellier, Place Eugène Bataillon, cc 1501, 34095 Montpellier Cedex 5, France and ${ }^{4}$ Institut de Chimie des Substances Naturelles, CNRS UPR 2301, Université Paris-Saclay, 1 Avenue de la Terrasse, 91198 Gif-sur-Yvette, France

Email:

Thomas-Xavier Métro* - thomas-xavier.metro@umontpellier.fr;

Frédéric Lamaty ${ }^{*}$ - frederic.lamaty@umontpellier.fr

* Corresponding author

Keywords:

ball mill; DFT calculations; diketopiperazine; mechanochemistry; pyrrolidine

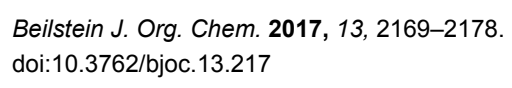

Received: 30 May 2017

Accepted: 21 September 2017

Published: 19 October 2017

This article is part of the Thematic Series "Mechanochemistry".

Guest Editor: J. G. Hernández

(C) 2017 Pétry et al.; licensee Beilstein-Institut.

License and terms: see end of document.

\begin{abstract}
Ball milling was exploited to prepare a substituted proline building block by mechanochemical nucleophilic substitution. Subsequently, the mechanocoupling of hindered proline amino acid derivatives was developed to provide proline-proline dipeptides under solvent-free conditions. A deprotection-cyclization sequence yielded the corresponding diketopiperazines that were obtained with a high stereoselectivity which could be explained by DFT calculations. Using this method, an enantiopure disubstituted Pro-Pro diketopiperazine was synthesized in 4 steps, making 5 new bonds using a ball mill.
\end{abstract}

\section{Introduction}

2,5-Diketopiperazines (DKPs) are heterocyclic structures, usually derived from dipeptides, which find many applications in chemistry and biology, and have attracted attention in the last years $[1,2]$. The diketopiperazine backbone can be found in many natural products exhibiting various biological activities
[3]. Consequently, medicinal chemists have used DKPs extensively as a synthetic platform, easily synthesized and stereochemically controlled, for the preparation of small bioactive molecules [4,5]. DKPs have also been considered as chiral auxiliaries in asymmetric synthesis [6]. Furthermore, the 
rigidity of the DKPs is a unique feature, used for the preparation of biologically active peptides and peptidomimetics [7], for applications in organocatalysis [8-10], and for the preparation of novel materials [11,12].

An interesting sub-family of these compounds are DKPs derived from the amino acid proline and its analogues, which provide a useful rigid structure. During the course of our project on the exploitation of dimethyl dibromoadipate as a synthon to access original molecules $[13,14]$, we thought that it could provide an original access to the DKP Pro-Pro framework. More specifically, this type of framework has been used as a scaffold for the preparation of small compound libraries [15].

The Pro-Pro diketopiperazine can be prepared directly by dimerization of unprotected proline in a one-pot transformation, generally under harsh conditions [16]. Good results were indeed reported, although this procedure gives access only to symmetrical products and can be detrimental for more fragile molecules such as substituted enantiomerically pure compounds. As shown by a retrosynthetic analysis (Scheme 1), a classical milder approach would consist in preparing first the dipeptide, followed by an intramolecular ester aminolysis. This strategy has been extensively used [1], involving milder conditions and provides access to unsymmetrical dipeptides and DKPs. Furthermore, substituted prolines could be obtained by nucleophilic substitution of benzylamine from dimethyl dibromoadipate, allowing the addition of functional groups on the Pro-Probased framework [17]. Recently, mechanochemistry has become a powerful synthetic technique for making new organic molecules $[18,19]$. In the course of this project, we applied mechanochemistry to a nucleophilic substitution and the efficient coupling of two proline residues.

\section{Results and Discussion}

First we studied the preparation of simple Pro-Pro DKP as a model compound. The use of ball milling in peptide synthesis has drawn some attention in the recent years [20-28]. We took advantage of our extensive experience in peptide mechanosynthesis $[20,23-25,27]$ to prepare the Pro-Pro dipeptide from the corresponding amino acid derivatives. We investigated the coupling of proline $N$-hydroxysuccinimide ester with proline methyl ester in a vibrating ball mill (vbm, Scheme 2) [23].

Surprisingly, while the coupling of various other amino acids previously used yielded the corresponding dipeptides [23], no<smiles>[R][CH]OC(C)=O</smiles>

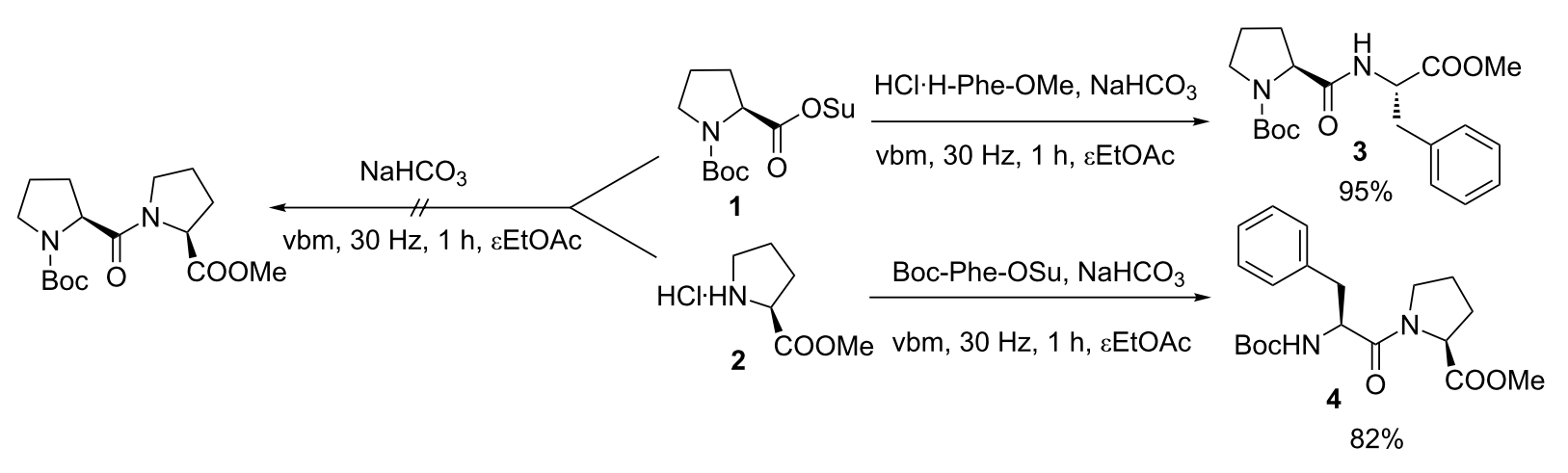


reaction occurred in the case of the two prolines $\mathbf{1}$ and $\mathbf{2}$, even by varying the reaction conditions. To verify the reactivity of either Boc-Pro-OSu (1) or H-Pro-OMe (2) in the mechanocoupling, we reacted $\mathrm{HCl} \cdot \mathrm{H}-\mathrm{Phe}-\mathrm{OMe}$ or Boc-Phe-OSu with respectively Boc-Pro-OSu and $\mathrm{HCl} \cdot \mathrm{H}-\mathrm{Pro}-\mathrm{OMe}$. In both cases, the reaction proceeded smoothly to give good yields of dipeptides 3 and 4 (95\% of Boc-Pro-Phe-OMe and $82 \%$ of Boc-Phe-Pro-OMe, respectively). Most probably, this method was less adapted to hindered amino acid derivatives such as proline.

As an alternative approach, we tested the optimal conditions developed previously for peptide mechanosynthesis [25], starting with unactivated amino acids together with a coupling agent. We had indeed reported two successful examples of couplings involving proline amino esters. The initial conditions, using 1-ethyl-3-(3-dimethylaminopropyl)carbodiimide (EDC), ethyl cyano(hydroxyimino)acetate (oxyma) in the presence of a base and a liquid additive, were adapted to the preparation of Z-Pro-Pro-OMe (7) and Boc-Pro-Pro-OMe (8, Table 1). It consisted in ball milling the two amino acid derivatives 5 or 6 with 2 in the presence of EDC (coupling agent), a base and a small amount [29] of EtOAc as liquid grinding assistant. The role of oxyma was mainly to suppress amino acid epimerization during the coupling, a limited problem in the case of proline. Consequently, our first experiments did not involve this reagent (Table 1, entries 1-3). Gratifyingly, the initial results showed that this method was adequate to prepare the Pro-Pro dipeptide 7 albeit in fair yield (Table 1, entry 1). Adding more starting material 6 (Table 1, entry 2) and changing the base
(Table 1, entry 3 ) did not provide much improvement. Finally supplementing the reaction mixture with oxyma (Table 1, entries 4-7) increased the yield up to $85-90 \%$ depending on the protection on the proline nitrogen (Boc or Z). Both of the bases gave similar yields (Table 1, entry 5 vs 7 and entry 4 vs 6). Eventually, as proposed before [25], $\mathrm{NaH}_{2} \mathrm{PO}_{4}$ was preferred since it would avoid a potential pressure build-up (release of $\mathrm{CO}_{2}$ ) which could occur with $\mathrm{NaHCO}_{3}$. Noteworthy, no epimerization could be detected by NMR or HPLC analyses.

Both peptides $\mathbf{7}$ and $\mathbf{8}$ were then deprotected and cyclized into the corresponding diketopiperazine 9. Palladium-catalyzed hydrogenolysis of the $\mathrm{Z}$ group of 7, in the presence of $\mathrm{NaHCO}_{3}$, in $\mathrm{MeOH}$, provided the DKP 9 in $83 \%$ yield. Compound 8 was deprotected with gaseous $\mathrm{HCl}$, and the resulting dipeptide was cyclized in the presence of $\mathrm{NaHCO}_{3}$, in $\mathrm{MeOH}$, yielding $70 \%$ of 9 (Scheme 3).

Then, as proposed above, we expanded this method to the preparation of substituted Pro-Pro DKPs. For this purpose, we considered using dimethyl $(2 R, 5 S)$-pyrrolidine-2,5-dicarboxylate (cis-11) as a building block in the synthesis of dipeptides and diketopiperazines. This building block was used in a very limited number of cases for the formation of DKP in combination with an amino acid derivative [30,31]. Original preparative conditions of the protected compound $\mathbf{1 1}$ consisted in performing a nucleophilic substitution of benzylamine with meso dimethyl-2,5-dibromohexanedioate (10) in benzene or toluene as solvent, yielding two diastereomers cis-11 (meso) and trans11 (racemic), which could be separated by crystallization or

Table 1: Optimization of the Pro-Pro coupling ${ }^{a}$.

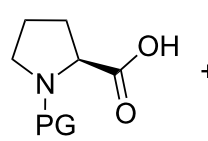

$5 P G=Z$

$6 P G=B o c$<smiles>[CH2+]C(=O)C(=O)C1CCCN1</smiles>

2

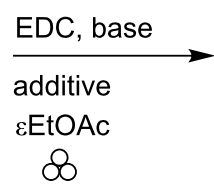

8

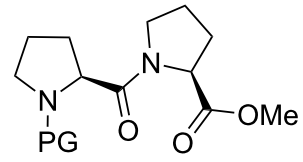

$7 \mathrm{PG}=\mathrm{Z}$

$8 P G=B O C$

\begin{tabular}{|c|c|c|c|c|c|c|}
\hline Entry & PG & equiv of 5 or $\mathbf{6}$ & Base (equiv) & Activating agent (equiv) & Reaction time & Yield (\%) \\
\hline 1 & Boc & 1.2 & $\mathrm{NaHCO}_{3}(3)$ & EDC (1.2) & $1 \mathrm{~h}$ & 65 \\
\hline 2 & Boc & $1.2+0.5$ & $\mathrm{NaHCO}_{3}(3)$ & EDC (1.5) & $2 \times 45 \min$ & 68 \\
\hline 3 & Boc & $1.2+0.5$ & $\mathrm{NaH}_{2} \mathrm{PO}_{4}(3)$ & EDC (1.5) & $2 \times 45 \min$ & 66 \\
\hline 4 & Boc & 1.2 & $\mathrm{NaHCO}_{3}(4)$ & EDC/oxyma (1.2) & $1 \mathrm{~h}$ & 78 \\
\hline 5 & Z & 1.2 & $\mathrm{NaHCO}_{3}(4)$ & EDC/oxyma (1.2) & $1 \mathrm{~h}$ & 90 \\
\hline 6 & Boc & 1.2 & $\mathrm{NaH}_{2} \mathrm{PO}_{4}(4)$ & EDC/oxyma (1.2) & $1 \mathrm{~h}$ & 85 \\
\hline 7 & Z & 1.2 & $\mathrm{NaH}_{2} \mathrm{PO}_{4}(4)$ & EDC/oxyma (1.2) & $1 \mathrm{~h}$ & 88 \\
\hline
\end{tabular}

${ }^{a}$ Reactions performed under air, in a vibrating ball mill (vbm) at $30 \mathrm{~Hz}$ with EtOAc (as a liquid grinding assistant). 


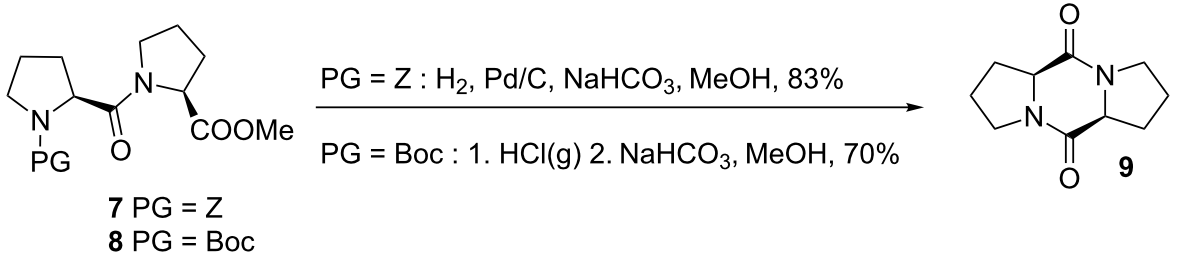

Scheme 3: Synthesis of Pro-Pro DKP

column chromatography $[17,32,33]$. Trying to avoid as much as possible the use of (toxic) solvents, we considered extending the known nucleophilic substitution in a ball mill [34-41] to this reaction system (Table 2 ).

For sake of comparison, we first performed the reaction between meso-10 and benzylamine in toluene (Table 2, entry 1) providing a full conversion into the expected product $\mathbf{1 1}$ with a 78:22 cis/trans ratio. Then we studied the mechanosynthesis of these compounds (Table 2, entries 2-8), starting by mixing an equimolar amount of the starting materials together with a base $\left(\mathrm{K}_{2} \mathrm{CO}_{3}\right)$ in a vibratory ball mill at $25 \mathrm{~Hz}$ (Table 2, entry 2 ). This resulted in a lower conversion compared to that obtained in solution. Using an excess of base increased the conversion to $62 \%$ (Table 2, entry 3). Switching to $\mathrm{Cs}_{2} \mathrm{CO}_{3}$ resulted in an increased conversion of $74 \%$ (Table 2 , entry 4 ), further improved to $82 \%$ when the milling frequency was adjusted to $30 \mathrm{~Hz}$ (Table 2, entry 5). Adding EtOAc as liquid grinding assistant did not improve the conversion, with either $\mathrm{K}_{2} \mathrm{CO}_{3}$ or $\mathrm{Cs}_{2} \mathrm{CO}_{3}$ (Table 2, entries 6 and 7). Finally, we tested the planetary ball mill (pbm) with the advantage of its capacity to produce more material. In this case (Table 2, entry 8), using cheaper $\mathrm{K}_{2} \mathrm{CO}_{3}$, full conversion was obtained and cis-11 was isolated in $75 \%$ yield and a larger amount of cis-11 could be prepared. Interestingly the cis/trans ratio (cis-11/trans-11) was different when the reaction was performed in solution (Table 2, entry 1) or in the ball mill (Table 2, entries 2-9) with a higher selectivity in the latter case [42].

With this building block in hands, the preparation of a variety of DKPs could be envisaged (Scheme 4).

Pyrrolidine cis-11 is an $N$-protected amino ester, which can be used in the synthesis of diketopiperazines by deprotecting either the amino group or the ester function. Hydrogenolysis of the benzyl group of cis-11 provided the nitrogen-free pyrrolidine derivative $\mathbf{1 2}$ in excellent yield and purity after filtration of the catalytic system. 12 was engaged without further purification in a coupling reaction with Z-proline (5) and Boc-proline (6), in the solvent-free conditions described above. In both cases, the

Table 2: Optimization of the substitution reaction.<smiles></smiles>

meso-10<smiles>NCc1ccccc1</smiles>

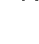

$\mathrm{NH}_{2}$

\begin{tabular}{|c|c|c|c|c|c|}
\hline Entry & equiv $\mathrm{BnNH}_{2}$ & Base (equiv) & Conditions & Conversion $^{a}$ & cis/trans-11 ratio \\
\hline 1 & 3 & - & toluene, $16 \mathrm{~h}$, reflux & 100 & $78: 22$ \\
\hline 2 & 1 & $\mathrm{~K}_{2} \mathrm{CO}_{3}(1.2)$ & vbm, $1 \mathrm{~h}, 25 \mathrm{~Hz}$ & 40 & $96: 04$ \\
\hline 3 & 1 & $\mathrm{~K}_{2} \mathrm{CO}_{3}(3)$ & vbm, $1 \mathrm{~h}, 25 \mathrm{~Hz}$ & 62 & $98: 02$ \\
\hline 4 & 1.1 & $\mathrm{Cs}_{2} \mathrm{CO}_{3}(3)$ & vbm, $1 \mathrm{~h}, 25 \mathrm{~Hz}$ & 74 & 91:09 \\
\hline 5 & 1.1 & $\mathrm{Cs}_{2} \mathrm{CO}_{3}(3)$ & vbm, $1 \mathrm{~h}, 30 \mathrm{~Hz}$ & 82 & $94: 06$ \\
\hline 6 & 1.1 & $\mathrm{~K}_{2} \mathrm{CO}_{3}(3)$ & vbm, $1 \mathrm{~h}, 30 \mathrm{~Hz}^{\mathrm{b}}$ & 49 & $98: 02$ \\
\hline 7 & 1.1 & $\mathrm{Cs}_{2} \mathrm{CO}_{3}(3)$ & vbm, $1 \mathrm{~h}, 30 \mathrm{~Hz}$ & 59 & $87: 13$ \\
\hline 8 & 1.3 & $\mathrm{~K}_{2} \mathrm{CO}_{3}(2.2)$ & pbm, 2 h, 500 rpm $^{b}$ & 97 & $97: 03$ \\
\hline
\end{tabular}

aMeasured by ${ }^{1} \mathrm{H}$ NMR ${ }^{b} \mathrm{EtOAc}$ was used as liquid grinding assistant. 
<smiles>COC(=O)[C@H]1CC[C@@H](OC)N1Cc1ccccc1</smiles>

cis -11

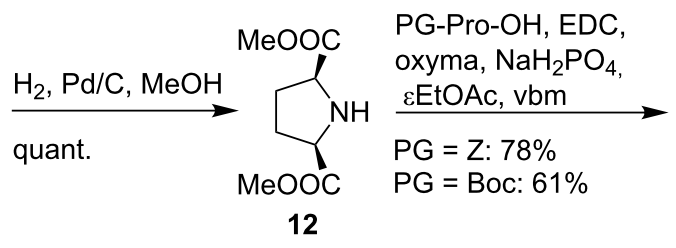

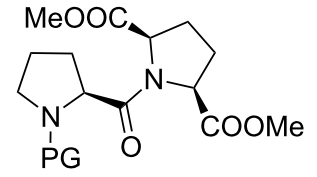

$13 P G=Z$

$14 P G=B o c$

$P G=\mathrm{Z}: \mathrm{H}_{2}, \mathrm{Pd} / \mathrm{C}, \mathrm{NaHCO}_{3}, \mathrm{MeOH}, 95 \%$

$P G=\mathrm{Boc}: 1 . \mathrm{HCl}(\mathrm{g}), 2 . \mathrm{NaHCO}_{3}, \mathrm{MeOH}, 80 \%$
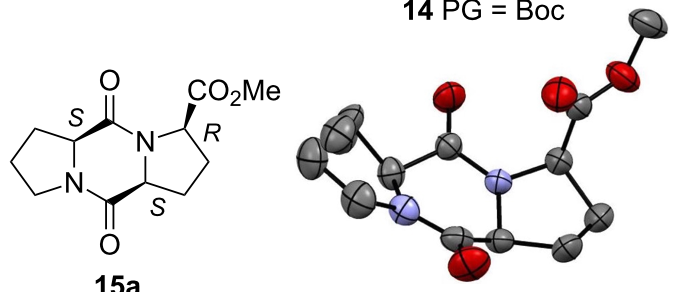

Scheme 4: Synthesis of substituted Pro-Pro DKP 15a

dipeptides 13 and $\mathbf{1 4}$ were obtained in good yields (78 and 61\%, respectively). Deprotection followed by cyclization provided the corresponding diketopiperazine 15a in 95\% yield (from 13) or $80 \%$ yield (from 14 ). In this case, two carboxymethyl groups could participate in the cyclization providing two possible diastereomers 15a and 15b (Scheme 5).

To our delight, this stereodivergent cyclization was selective and only one diastereomer was obtained, as supported by analytical data. X-ray analysis of the product confirmed the stereochemistry of the three chiral centres and the structure of $\mathbf{1 5 a}$.

To shed more light on the origin of the selectivity observed in the deprotection-cyclization transformation, DFT calculations of the reaction mechanism have been carried out. DFT calculations were applied to the various pathways starting from the deprotected amine $\mathbf{1 6}$ and reaction pathways leading to either product 15a, resulting from nucleophilic attack of the amine on $\mathrm{C}_{\mathrm{a}}$, or to product $\mathbf{1 5 b}$ resulting from attack on $\mathrm{C}_{\mathrm{b}}$, were considered (Scheme 5).

The first step was to study if there was any preferential interaction between the free nitrogen atom and either $\mathrm{C}_{\mathrm{a}}$ or $\mathrm{C}_{\mathrm{b}}$ before the $\mathrm{C}-\mathrm{N}$ bond formation. Both optimized structures are shown in Figure 1, and compound 16a is computed to be less stable than $16 \mathrm{~b}$ by $\Delta G=2.7 \mathrm{kcal} \mathrm{mol}^{-1}$. The $\mathrm{C} \cdots \mathrm{N}$ bond distance is slightly shorter in 16b $(2.673 \AA)$ than in 16a (2.682 $\AA$ ). Many attempts to locate a transition state structure for the $\mathrm{C}-\mathrm{N}$ bond

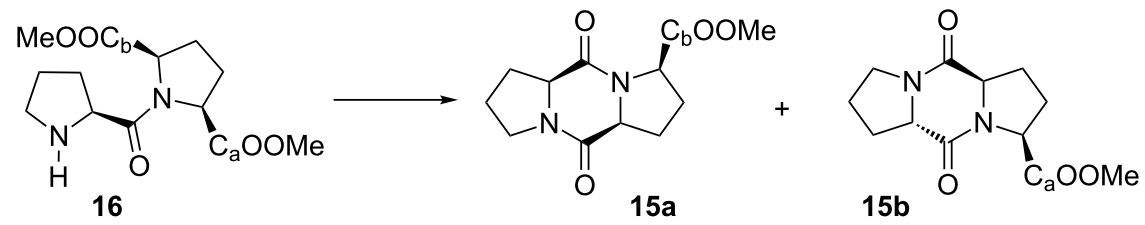

Scheme 5: Potential isomers yielded by cyclization of 16 .

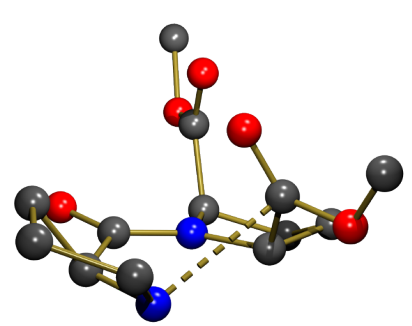

$16 a$

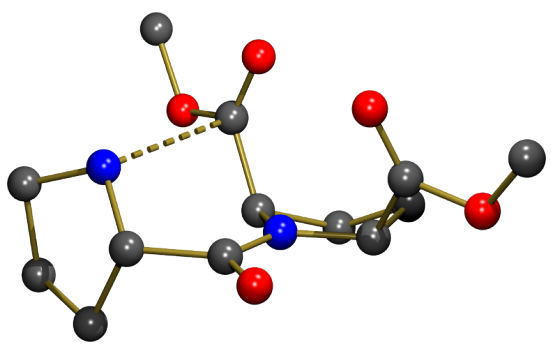

$16 b$

Figure 1: Optimized geometries for the two conformers presenting interactions with either $\mathrm{C}_{a}(\mathbf{1 6 a})$ or $\mathrm{C}_{b}(\mathbf{1 6 b})$. $\mathrm{H}$ atoms were omitted for clarity. 
formation starting from either $\mathbf{1 6 a}$ or $\mathbf{1 6 b}$ failed. Even though the geometry optimizations were performed with implicit inclusion of the solvent influence (SMD model with methanol), the zwitterionic character developing in the $\mathrm{C}-\mathrm{N}$ bond formation could not be stabilized. However, the protic methanol solvent could act both as a base to abstract the proton from the nitrogen atom, and as an acid to facilitate the $\mathrm{C}-\mathrm{OMe}$ bond cleavage. Transition state structures with combined implicit (SMD model) and explicit inclusion of the solvent were thus searched for.

The geometry of 16a allowed the creation of a network of stabilizing interactions between an explicit methanol solvent molecule and both the $\mathrm{N}-\mathrm{H}$ proton and the OMe group $(\mathrm{N}-\mathrm{H} \cdots \mathrm{O}=$ $2.153 \AA, \mathrm{H} \cdots \mathrm{OMe}=1.925 \AA$; see 16a-solv in Figure 2 ). 16a-solv was computed to be less stable than $\mathbf{1 6 a}$ by $\Delta G=9.3 \mathrm{kcal} \mathrm{mol}^{-1}$. This higher Gibbs free energy was due only to entropic factors as $\mathbf{1 6} \mathbf{a}-\mathbf{s o l v}$ was computed to be more stable than $16 \mathrm{a}$ by $\Delta E=-4.0 \mathrm{kcal} \mathrm{mol}^{-1}$. Interestingly, upon interaction with an explicit methanol molecule the $\mathrm{C} \cdot \cdots \mathrm{N}$ distance in 16a-solv had been reduced to $2.464 \AA$ compared to a value of $2.682 \AA$ in $\mathbf{1 6 a}$. A transition state structure, TS-16a-solv, corresponding to a concerted C-N bond formation and a $\mathrm{C}-\mathrm{OMe}$ bond cleavage could be located (Figure 2). Table 3 collects selected bond distances associated to the transformation. In the transition state, the $\mathrm{C}-\mathrm{OMe}$ bond cleavage was well advanced and the $\mathrm{C}-\mathrm{N}$ bond formation was also almost complete. This indicated that the transformation was concerted and that the explicit methanol molecule only acted as a relay to accept the proton from the amine and to facilitate the departing of the methoxy group by transferring a proton. The activation energy from 16a-solv was computed to be $\Delta G^{\#}=22.8 \mathrm{kcal} \mathrm{mol}^{-1}$, in good agreement with an easy reaction at room temperature. The reaction was strongly exoergic with $\Delta \mathrm{G}=-17.3 \mathrm{kcal} \mathrm{mol}^{-1}$ and the geometry of 15a-solv (Figure 2) had the stereochemistry expected for $\mathbf{1 5 a}$ (Scheme 5).

Table 3: Selected bond distances $(\AA)$ for the structures optimized along the transformation 16 a-solv $\rightarrow 15 a-s o l v$.

\begin{tabular}{llll} 
Bond & 16a-solv & TS-16a-solv & 15a-solv \\
\hline $\mathrm{N}-\mathrm{H}$ & 1.077 & 1.167 & 2.310 \\
$\mathrm{NH} \cdots \mathrm{O}$ & 2.153 & 1.341 & 0.965 \\
$\mathrm{MeO}-\mathrm{H}$ & 0.970 & 1.226 & 1.761 \\
$\mathrm{H} \cdots \mathrm{OMe}$ & 1.925 & 1.117 & 0.979 \\
$\mathrm{C}-\mathrm{OMe}$ & 1.340 & 1.935 & 3.784 \\
$\mathrm{~N}-\mathrm{C}$ & 2.464 & 1.500 & 1.343 \\
& & & \\
\end{tabular}

The geometry of $\mathbf{1 6} \mathbf{b}$ did not allow creating a similar network of H-bonding interactions when one explicit molecule of methanol was considered. The $\mathrm{N}-\mathrm{H}$ bond is pointed in a direction of space remote from the methoxy group of the ester functionality. Rotation by $180^{\circ}$ around the $\mathrm{C}-\mathrm{C}$ bond of the ester led to a geometry in which a methanol molecule could interact with both groups as illustrated in $\mathbf{1 6 b}$-solv (Figure 3). This structure was computed to be more stable than 16a-solv by $\Delta G=-3.8 \mathrm{kcal} \mathrm{mol}^{-1}$, probably because in addition to the expected $\mathrm{H}$-bonds between $\mathrm{N}-\mathrm{H}$ and $\mathrm{O}(\mathrm{N}-\mathrm{H} \cdots \mathrm{O}=2.123 \AA)$, and between $\mathrm{O}-\mathrm{H}$ and $\mathrm{OMe}(\mathrm{H} \cdots \mathrm{OMe}=2.488 \AA)$, there existed an additional $\mathrm{H}$-bond with the other ester functionality $(\mathrm{H} \cdots \mathrm{OC}=$ $1.873 \AA$ ). However, despite the greater stability of $\mathbf{1 6 b}$-solv, the concerted formation of $\mathrm{C}-\mathrm{N}$ and cleavage of the $\mathrm{C}-\mathrm{OMe}$ bond through TS-16b-solv was associated to a higher activation barrier with $\Delta G^{\#}=30.0 \mathrm{kcal} \mathrm{mol}^{-1}$ and a less exoergic reaction

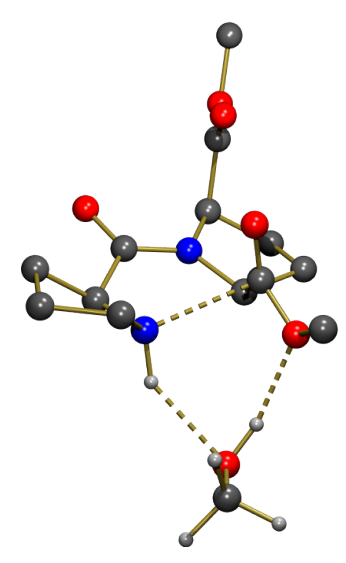

16a-solv

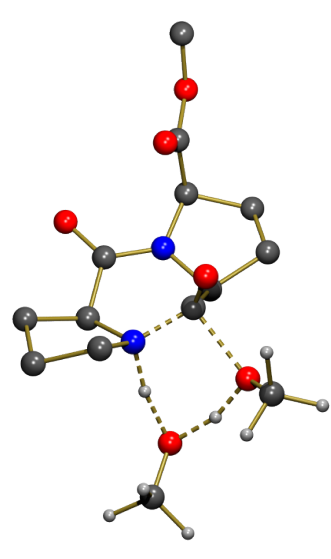

TS-16a-solv

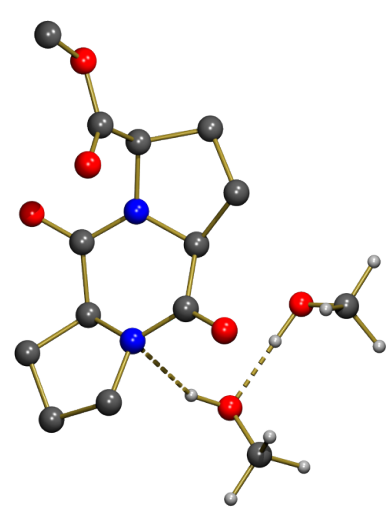

15a-solv

Figure 2: Optimized geometries of the extrema located along the pathway for formation of 15a with explicit participation of one solvent molecule. Most $\mathrm{H}$ atoms were omitted for clarity. 


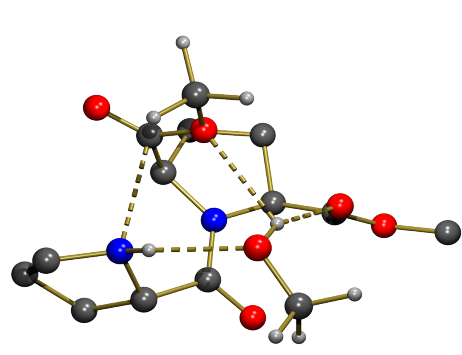

16b-solv

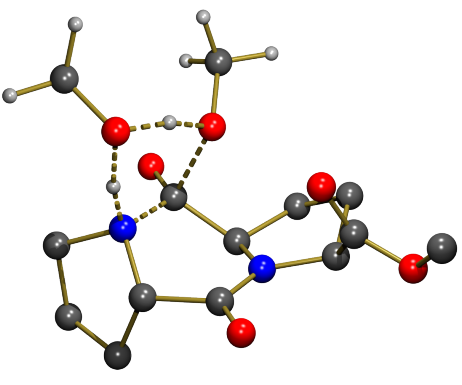

TS-16b-solv

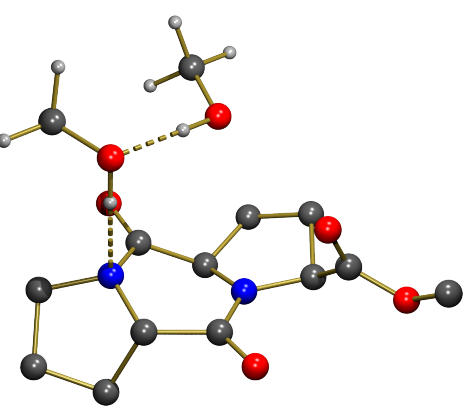

15b-solv

Figure 3: Optimized geometries of the extrema located along the pathway for formation of $\mathbf{1 5 b}$ with explicit participation of one solvent molecule. Most $\mathrm{H}$ atoms were omitted for clarity.

$\left(\Delta G=-2.6 \mathrm{kcal} \mathrm{mol}^{-1}\right)$. Selected bond distances in Table 4 clearly show that the formation of $\mathrm{C}-\mathrm{N}$ and cleavage of $\mathrm{C}-\mathrm{O}$ are both well advanced in TS-16b-solv, similarly to the situation observed in TS-16a-solv. The essential difference was the significant longer $\mathrm{C} \cdots \mathrm{N}$ distance in 16b-solv (2.625 $\AA$ vs 2.464 $\AA$ in 16a-solv), and the longer H-bond between the methanol molecule and the methoxy group in 16b-solv (2.488 $\AA$ ) compared to that observed in 16a-solv (1.925 $\AA$ ). The origin of these differences lied in the presence of an H-bond between the methanol molecule and the carbonyl group of the other ester functionality. This interaction stabilized a geometry with a longer $\mathrm{C} \cdots \mathrm{N}$ distance, and destabilized the transition state structure as it needed to be lost in TS-16b-solv $(\mathrm{H} \cdots \mathrm{OC}=3.326 \AA$ vs $1.873 \AA$ in $\mathbf{1 6 b}-\mathbf{s o l v})$.

There was thus a significant energetic preference for the formation of $\mathbf{1 5 a}$ with respect to $\mathbf{1 5} \mathbf{b}$ with a $\Delta \Delta G^{\#}=7.3 \mathrm{kcal} \mathrm{mol}^{-1}$. However, the positions of the methanol molecule in
Table 4: Selected bond distances $(\AA)$ for the structures optimized along the transformation $16 \mathrm{~b}$-solv $\rightarrow \mathbf{1 5 b}$-solv.

\begin{tabular}{llll} 
Bond & $\mathbf{1 6 b}-\mathbf{s o l v}$ & TS-16b-solv & $\mathbf{1 5 b}$-solv \\
\hline $\mathrm{N}-\mathrm{H}$ & 1.018 & 1.165 & 2.014 \\
$\mathrm{NH} \cdots \mathrm{O}$ & 2.123 & 1.342 & 0.971 \\
$\mathrm{MeO}-\mathrm{H}$ & 0.973 & 1.212 & 1.751 \\
$\mathrm{H} \cdots \mathrm{OMe}$ & 2.488 & 1.182 & 0.979 \\
$\mathrm{C}-\mathrm{OMe}$ & 1.326 & 1.940 & 3.333 \\
$\mathrm{~N}-\mathrm{C}$ & 2.625 & 1.521 & 1.365
\end{tabular}

TS-16a-solv and TS-16b-solv were significantly different, and this could be the origin of the stability of the former. Therefore a transition state structure leading to $\mathbf{1 5 b}$ with the methanol molecule in an "exo" position was optimized (TSbis-16b-solv, Figure 4). This transition state was less stable than TS-16b-solv by $2.9 \mathrm{kcal} \mathrm{mol}^{-1}$. Alternatively, a transition state structure
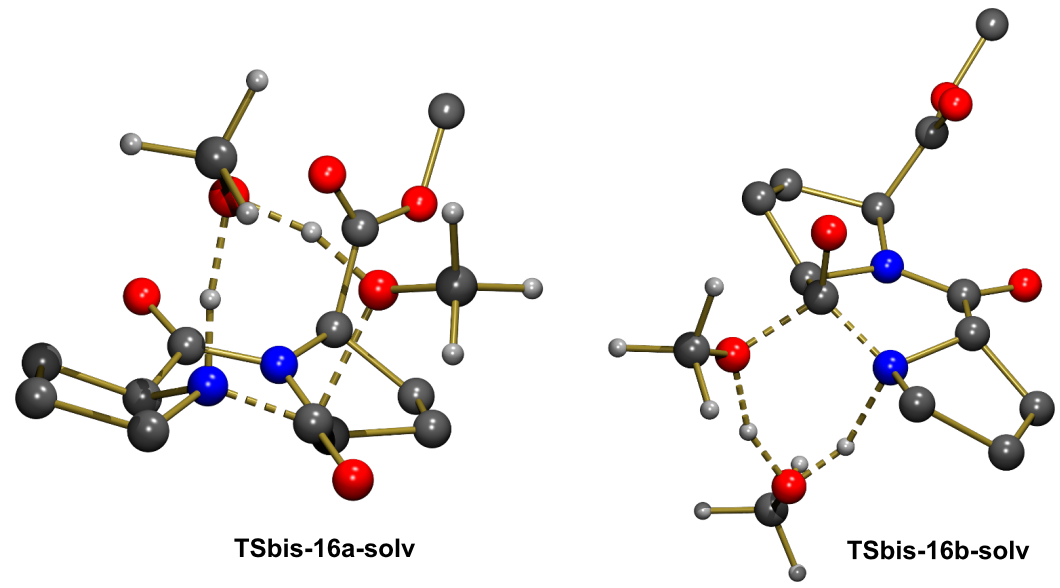

Figure 4: Optimized geometries for the transition states associated to alternate position of the methanol molecule. Most $\mathrm{H}$ atoms were omitted for clarity. 
leading to $\mathbf{1 5 a}$ with a methanol molecule in an "endo" position was located (TSbis-16a-solv, Figure 4). This structure was computed to be less stable than TS-16a-solv by $3.9 \mathrm{kcal} \mathrm{mol}^{-1}$. The calculations thus clearly indicated that there was a low lying pathway for the formation of 15a consisting in a concerted $\mathrm{C}-\mathrm{N}$ bond formation and $\mathrm{C}-\mathrm{OMe}$ bond cleavage mediated by a solvent methanol molecule acting as both a proton acceptor from $\mathrm{N}-\mathrm{H}$ and a proton donor to OMe. All the alternative pathways were associated to transition states lying at significantly higher energy not to be observed experimentally. This was in agreement with the experimental formation of only $15 a$.

As mentioned above, another possibility to exploit meso pyrrolidine cis-11 would be to desymmetrize [43] the ester functions by selective hydrolysis. The corresponding carboxylic acid could then be engaged in a peptide coupling. Pig liver esterase (PLE)-catalyzed enzymatic hydrolysis of meso cis-11 provided selectively the $N$-protected amino acid $\mathbf{1 7}$ as one enantiomer $[33,44,45]$. Mechanocoupling of $\mathbf{1 7}$ with pyrrolidine $\mathbf{1 2}$ provided the dipeptide 18 in excellent yield. Removal of the benzyl group by hydrogenation in the presence of $\mathrm{Pd}(\mathrm{OH})_{2} / \mathrm{C}$ followed by cyclization provided unprecedented DKP 19 in 52\% yield. In this case again, spectral data and X-ray analysis showed the selective formation of diketopiperazine $\mathbf{1 9}$ as only one isomer (Scheme 6).

\section{Conclusion}

In summary, we have developed an efficient synthesis of two enantiopure substituted diketopiperazines based on the proline-proline framework. The synthetic schemes included two key reactions, which were performed under mechanochemical conditions, including a peptide coupling leading to the formation of Pro-Pro dipeptides, and a nucleophilic substitution furnishing substituted proline derivatives. The diastereoselec- tive cyclization, which was clearly supported by DFT calculations is noteworthy. Further developments and applications of these scaffolds are currently underway.

\section{Supporting Information}

Experimental procedures and characterization of new compounds, X-ray data including CCDC numbers and CIF files.

\section{Supporting Information File 1 \\ Experimental part. \\ [http://www.beilstein-journals.org/bjoc/content/ supplementary/1860-5397-13-217-S1.pdf]}

\section{Supporting Information File 2}

Crystallographic data.

[http://www.beilstein-journals.org/bjoc/content/ supplementary/1860-5397-13-217-S2.pdf]

\section{Supporting Information File 3}

X-ray of meso-10.

[http://www.beilstein-journals.org/bjoc/content/ supplementary/1860-5397-13-217-S3.cif]

\section{Supporting Information File 4}

X-ray of 15a.

[http://www.beilstein-journals.org/bjoc/content/ supplementary/1860-5397-13-217-S4.cif]

\section{Supporting Information File 5}

$\mathrm{X}$-ray of 19.

[http://www.beilstein-journals.org/bjoc/content/ supplementary/1860-5397-13-217-S5.cif]

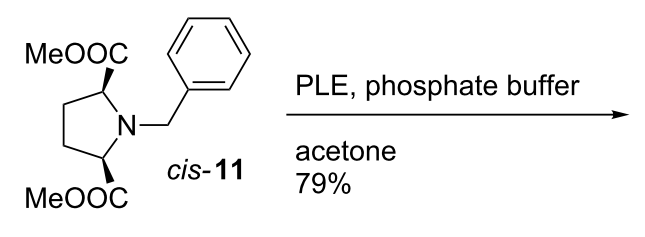<smiles>CO[C@H]1CC[C@@H](C(=O)O)N1Cc1ccccc1</smiles>

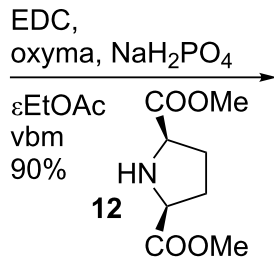<smiles>COC(=O)[C@@H]1CCC(C(=O)N2[C@H](C(=O)OC)CC[C@H]2C(=O)OC)N1Cc1ccccc1</smiles><smiles>[R]C1CC[C@H]2C(=O)N3C(C(C)=O)[C@@H](CC[C@H]3COC)C(=O)N12</smiles> 


\section{Acknowledgements}

The authors thank the Centre National de la Recherche Scientifique (CNRS) and Université de Montpellier for financial support.

\section{References}

1. Borthwick, A. D. Chem. Rev. 2012, 112, 3641-3716. doi:10.1021/cr200398y

2. Martins, M. B.; Carvalho, I. Tetrahedron 2007, 63, 9923-9932. doi:10.1016/j.tet.2007.04.105

3. Huang, R.-M.; Yi, X.-X.; Zhou, Y.; Su, X.; Peng, Y.; Gao, C.-H. Mar. Drugs 2014, 12, 6213-6235. doi:10.3390/md12126213

4. González, J. F.; Ortin, I.; de la Cuesta, E.; Menéndez, J. C. Chem. Soc. Rev. 2012, 41, 6902-6915. doi:10.1039/c2cs35158g

5. Cornacchia, C.; Cacciatore, I.; Baldassarre, L.; Mollica, A.; Feliciani, F.; Pinnen, F. Mini-Rev. Med. Chem. 2012, 12, 2-12. doi:10.2174/138955712798868959

6. Sano, S.; Nakao, M. Heterocycles 2015, 91, 1349-1375. doi:10.3987/REV-15-820

7. Ressurreição, A. S. M.; Delatouche, R.; Gennari, C.; Piarulli, U. Eur. J. Org. Chem. 2011, 217-228. doi:10.1002/ejoc.201001330

8. Durini, M.; Sahr, F. A.; Kuhn, M.; Civera, M.; Gennari, C.; Piarulli, U. Eur. J. Org. Chem. 2011, 5599-5607. doi:10.1002/ejoc.201100794

9. Becker, C.; Hoben, C.; Schollmeyer, D.; Scherr, G.; Kunz, H. Eur. J. Org. Chem. 2005, 1497-1499. doi:10.1002/ejoc.200500044

10. lyer, M. S.; Gigstad, K. M.; Namdev, N. D.; Lipton, M. J. Am. Chem. Soc. 1996, 118, 4910-4911. doi:10.1021/ja952686e

11. Kleinsmann, A. J.; Nachtsheim, B. J. Chem. Commun. 2013, 49, 7818-7820. doi:10.1039/c3cc44110e

12. Xie, Z.; Zhang, A.; Ye, L.; Feng, Z.-g. Soft Matter 2009, 5, 1474-1482. doi:10.1039/b816664a

13. Lenda, F.; Guenoun, F.; Tazi, B.; Ben larbi, N.; Allouchi, H.; Martinez, J.; Lamaty, F. Eur. J. Org. Chem. 2005, 326-333. doi:10.1002/ejoc.200400328

14. Lenda, F.; Crouzin, N.; Cavalier, M.; Guiramand, J.; Lanté, F.; Barbanel, G.; Cohen-Solal, C.; Martinez, J.; Guenoun, F.; Lamaty, F.; Vignes, M. Amino Acids 2011, 40, 913-922. doi:10.1007/s00726-010-0713-1

15. Deppermann, N.; Prenzel, A. H. G. P.; Beitat, A.; Maison, W. J. Org. Chem. 2009, 74, 4267-4271. doi:10.1021/jo9004876

16. Nakamura, D.; Kakiuchi, K.; Koga, K.; Shirai, R. Org. Lett. 2006, 8 , 6139-6142. doi:10.1021/ol0626387

17. Cignarella, G.; Nathansohn, G. J. Org. Chem. 1961, 26, 1500-1504. doi:10.1021/jo01064a046

18. James, S. L.; Adams, C. J.; Bolm, C.; Braga, D.; Collier, P.; Friščić, T.; Grepioni, F.; Harris, K. D. M.; Hyett, G.; Jones, W.; Krebs, A.; Mack, J.; Maini, L.; Orpen, A. G.; Parkin, I. P.; Shearouse, W. C.; Steed, J. W.; Waddell, D. C. Chem. Soc. Rev. 2012, 41, 413-447. doi:10.1039/C1CS15171A

19. Wang, G.-W. Chem. Soc. Rev. 2013, 42, 7668-7700. doi:10.1039/c3cs35526h

20. Declerck, V.; Nun, P.; Martinez, J.; Lamaty, F. Angew. Chem., Int. Ed. 2009, 48, 9318-9321. doi:10.1002/anie.200903510

21. Hernández, J. G.; Juaristi, E. J. Org. Chem. 2010, 75, 7107-7111. doi:10.1021/jo101159a

22. Štrukil, V.; Bartolec, B.; Portada, T.; Đilović, I.; Halasz, I.; Margetić, D Chem. Commun. 2012, 48, 12100-12102. doi:10.1039/c2cc36613d

23. Bonnamour, J.; Métro, T.-X.; Martinez, J.; Lamaty, F. Green Chem. 2013, 15, 1116-1120. doi:10.1039/c3gc40302e
24. Métro, T.-X.; Colacino, E.; Martinez, J.; Lamaty, F. Amino Acids and Peptides in Ball Milling. In Ball Milling Towards Green Synthesis: Applications, Projects, Challenges; Stolle, A.; Ranu, B., Eds.; RSC Green Chem. Ser., Vol. 31; Royal Society of Chemistry: Cambridge, UK, 2015; pp 114-150. doi:10.1039/9781782621980-00114

25. Porte, V.; Thioloy, M.; Pigoux, T.; Métro, T.-X.; Martinez, J.; Lamaty, F. Eur. J. Org. Chem. 2016, 3505-3508. doi:10.1002/ejoc.201600617

26. Landeros, J. M.; Juaristi, E. Eur. J. Org. Chem. 2017, 687-694. doi:10.1002/ejoc.201601276

27. Gonnet, L.; Tintillier, T.; Venturini, N.; Konnert, L.; Hernandez, J.-F.; Lamaty, F.; Laconde, G.; Martinez, J.; Colacino, E. ACS Sustainable Chem. Eng. 2017, 5, 2936-2941. doi:10.1021/acssuschemeng.6b02439

28. Hernández, J. G.; Ardila-Fierro, K. J.; Crawford, D.; James, S. L.; Bolm, C. Green Chem. 2017, in press.

29. Bowmaker, G. A. Chem. Commun. 2013, 49, 334-348. doi:10.1039/C2CC35694E

30. Guenoun, F.; Zair, T.; Lamaty, F.; Pierrot, M.; Lazaro, R.; Viallefont, P. Tetrahedron Lett. 1997, 38, 1563-1566. doi:10.1016/S0040-4039(97)00130-5

31. Yu, W.; Vibulbhan, B.; Rosenblum, S. B.; Martin, G. S.; Vellekoop, A. S.; Holst, C. L.; Coburn, C. A.; Wong, M.; Selyutin, O.; Ji, T.; Zhong, B.; Hu, B.; Chen, L.; Dwyer, M. P.; Jiang, Y.; Nair, A. G.; Tong, L.; Zeng, Q.; Agrawal, S.; Carr, D.; Rokosz, L.; Liu, R.; Curry, S.; McMonagle, P.; Ingravallo, P.; Lahser, F.; Asante-Appiah, E.; Fells, J.; Kozlowski, J. A. Bioorg. Med. Chem. Lett. 2016, 26, 3793-3799. doi:10.1016/j.bmcl.2016.05.042

32. Kubyshkin, V. S.; Mykhailiuk, P. K.; Ulrich, A. S.; Komarov, I. Synthesis 2009, 3327-3331. doi:10.1055/s-0029-1216963

33. Chiaroni, A.; Riche, C.; Zair, T.; Guenoun, F.; Lazaro, R.; Viallefont, P. Acta Crystallogr., Sect. C: Cryst. Struct. Commun. 1997, 53, 459-461. doi:10.1107/S0108270196014606

34. Nun, P.; Martin, C.; Martinez, J.; Lamaty, F. Tetrahedron 2011, 67, 8187-8194. doi:10.1016/j.tet.2011.07.056

35. Nun, P.; Pérez, V.; Calmès, M.; Martinez, J.; Lamaty, F. Chem. - Eur. J. 2012, 18, 3773-3779. doi:10.1002/chem.201102885

36. Beillard, A.; Golliard, E.; Gillet, V.; Bantreil, X.; Métro, T.-X.; Martinez, J.; Lamaty, F. Chem. - Eur. J. 2015, 21, 17614-17617. doi:10.1002/chem.201503472

37. Jörres, M.; Aceña, J. L.; Soloshonok, V. A.; Bolm, C. ChemCatChem 2015, 7, 1265-1269. doi:10.1002/cctc.201500102

38. Abdulwahaab, B. H.; Burke, B. P.; Domarkas, J.; Silversides, J. D.; Prior, T. J.; Archibald, S. J. J. Org. Chem. 2016, 81, 890-898. doi:10.1021/acs.joc.5b02464

39. Hernández, J. G.; Turberg, M.; Schiffers, I.; Bolm, C. Chem. - Eur. J. 2016, 22, 14513-14517. doi:10.1002/chem.201603057

40. Sethi, K. P.; Kartha, K. P. R. Trends Carbohydr. Res. 2016, 8, 29-32.

41. Métro, T.-X.; Salom-Roig, X. J.; Reverte, M.; Martinez, J.; Lamaty, F. Green Chem. 2015, 17, 204-208. doi:10.1039/C4GC01416B

42. Hernández, J. G.; Bolm, C. J. Org. Chem. 2017, 82, 4007-4019. doi:10.1021/acs.joc.6b02887

43. Merad, J.; Candy, M.; Pons, J.-M.; Bressy, C. Synthesis 2017, 49, 1938-1954. doi:10.1055/s-0036-1589493

44. Morimoto, Y.; Terao, Y.; Achiwa, K. Chem. Pharm. Bull. 1987, 35 , 2266-2271. doi:10.1248/cpb.35.2266

45. Chênevert, R.; Jacques, F.; Giguère, P.; Dasser, M. Tetrahedron: Asymmetry 2008, 19, 1333-1338. doi:10.1016/j.tetasy.2008.05.022 


\section{License and Terms}

This is an Open Access article under the terms of the Creative Commons Attribution License

(http://creativecommons.org/licenses/by/4.0), which permits unrestricted use, distribution, and reproduction in any medium, provided the original work is properly cited.

The license is subject to the Beilstein Journal of Organic Chemistry terms and conditions:

(http://www.beilstein-journals.org/bjoc)

The definitive version of this article is the electronic one which can be found at:

doi:10.3762/bjoc.13.217 